\title{
CELTO - GALLO - ROMAN STUDIES OF THE MTA-ELTE RESEARCH GROUP FOR INTERDISCIPLINARY ARCHAEOLOGY, EDITED BY L. BORHY, K. DÉVAI, AND K. TANKÓ
}

\section{Tamás SzabadváRY}

Hungarian Archaeology Vol. 8 (2019), Issue 3, pp. 41-43, https://doi.org/10.36338/ha.2019.3.7

The Research Group for Interdisciplinary Archaeology - funded by Miklós Szabó in 1999 and jointly hosted by the Hungarian Academy of Science and the Eötvös Loránd University - has produced numerous results of significant scientific value, not only within the Hungarian, but also on the international scene. The present volume - published by L'Harmattan, Paris and edited by L. Borhy, K. Dévai and K. Tankó -, is a collection of 14 essays by 20 authors in English (9), French (3) and German (2) languages. The essays divide into the following thematic groups: research carried out by the French-Hungarian research group at the antique Bibracte (today Mont Beuvray) (2); numismatic and iconographic aspects of Romanization from $1 \mathrm{c} . B C$ to $2 \mathrm{c}$. AD (1); the anthropological evaluation of the Late Iron Age cemetery in Povegliano (1); systematic excavations in Brigetio (today Komárom-Szöny), carried out by members of the Archaeological Institute of the Eötvös Loránd University, Faculty of Humanities and the Gyorgy Klapka Museum in Komarom. Essays in the latter group concern the legionary fortress, the military town (canabae), the civil town (municipium), the cemeteries, the localization of earlier excavation sites, and material culture in general, and they demonstrate the extensive application of scientific methods (anthropology, aerial archaeology, and GIS), primarily in connection to investigations carried out in the past few years (9); the Barbaricum in the Late Roman period (1).

\section{Celto - Gallo - Roman}

Studies of the MTA-ELTE Research Group for Interdisciplinary Archaeology

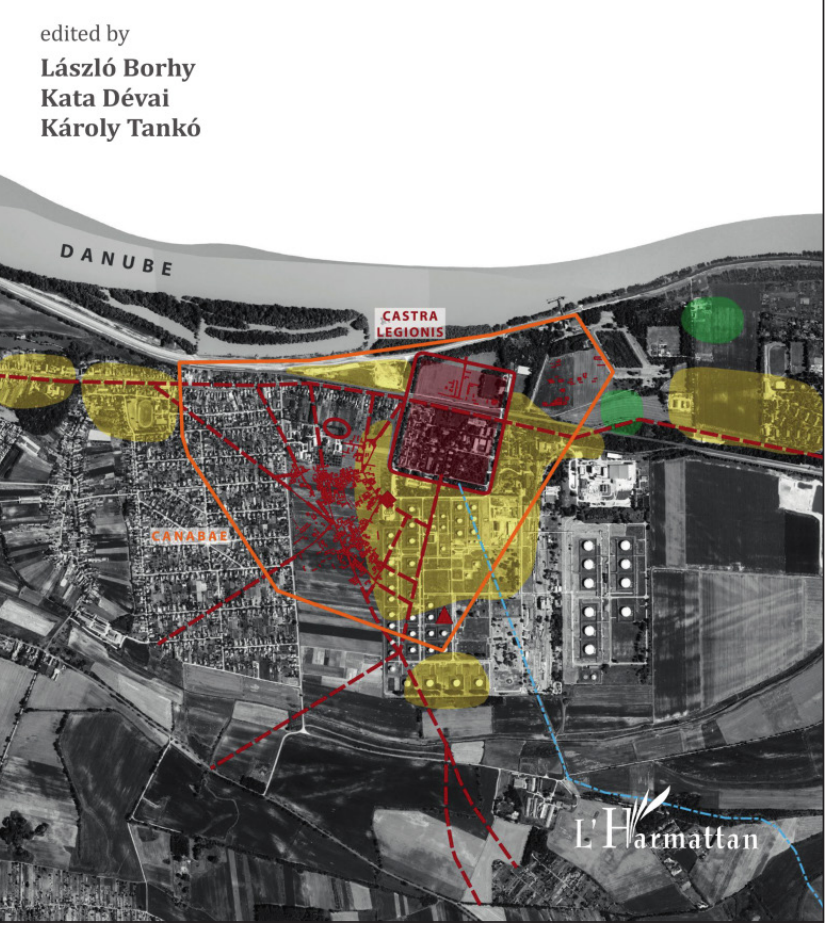

L. Borhy, K. Dévai, K. Tankó (eds.), Celto - Gallo-Roman Studies of the MTA-ELTE Research Group for Interdisciplinary Archaeology.

Paris: L'Harmattan, 2018

\section{Hardcover, 311 pages, 178 figures} ISBN 978-2-343-16091-7

In their essay, M. Szabó, L. Tímár and D. Szabó (pp. 11-26) are looking for points of reference in connection to interpretive problems regarding the structure and building history of the domus and the earlier basilica in Bibracte ("l'îlot des Grandes Forges"). They conclude with a highly significant statement, that the plan of the basilica follows the style typical for the period of the Late Republic (with perystilium and an exterior claustral space). The ceramic finds seem to confirm this chronological background (La Tène D2b - ca. 50/30 BC), thus, the building is the first archaeologically documented example of its kind. A separate study is dedicated to the composition of ceramic finds from the basilica by D. Szabó (pp. 27-34), focusing particularly on the 2009/1 sondage. He observes the total absence of certain finds (such as terra sigillata, ACO beakers, and jars with ribbed rims), which supports the dating of the structure before the Augustus 
period. É. Bózsing's essay (pp. 35-44) presents the results of the anthropological analysis of thirteen multiple cremations from the Late Iron Age cemetery in Povegliano Ortaia. There were calcinated bones of adults and children found in these graves, and on the basis of archaeological evidence, the examples when the individuals were cremated together (based on the mixed bones, and the temperature) could be clearly separated from those when they were cremated individually (i.e. when the bones belonged to one person only, or when the temperature of cremations differed). Based on Roman coinage, L. Juhász's essay (pp. 45-62) highlights some iconographic aspects of the Romanization process. Primarily focusing on the representations and attributes of the provinces of Gallia, Hispania and Dacia, he evaluates the centrally defined visual tools, to the changes of which the internal conflicts significantly contributed. D. Bartus, L. Borhy, N. Sey and E. Számadó summarize the results of the excavations conducted in the area of Brigetio in 2012 2016. Regarding the Szöny-Vásártér site, a significant discovery was a cellar (2), unearthed in 2012, whose wooden plank ceiling (which served, at once, as the floor of the upper chamber) preserved in excellent condition. Among the rich finds, a stamped glass vessel ("L PVBLIC"), a bronze cavalry parade helmet, and an amphora (Dress. 20) - used for the transportation of olive oil - should be noted. During the summer of 2014 , a rescue excavation took place in the area of the canabae, where there had been no systematic excavations before, and in the western zone of the excavation area the remains of a building were found, with a hypocaust system, covered with a (possibly painted) terrazzo floor, which could be dated to the period between the end of the 2nd century and the end of the Late Roman Period, There was also a praefurnium, which was in operation in two different periods. The building was hypothetically identified as a bathhouse. East of this structure, the massive walls of a large horreum were found in 2015, and a smaller rectangular building was also identified (possibly another horreum). From among the finds, the most prominent one was a Vespasianus aureus. In 2015, there have been further investigations carried out in the area of the legionary camp (Komárom-Szöny-MOL-Kiskertek), where the fragments of the bronze plaque of Philippus I. Arabus were found during metal detector surveys (in the eastern segment of the survey area). Surprisingly, a matching fragment - the lower part of the plaque -, was found there in the Late Roman layers during the subsequent excavation of the area. The line of a north-south road could be also identified, which was covered with stone plates in the era of the Severus dynasty. In the drainage gully, on the eastern side of this road, a grotesque bronze head, the decoration of a cart, was found. Within the suggested zone of the principia, there were two trenches opened, where several cultural layers - representing five different periods - were unearthed. L. Rupnik, Z. Czajlik and D. Bartus (pp. 83-96) summarized the results of complex aerial photographical, non-invasive and GIS investigations, which have been conducted in the past years. Complementing this research, archival aerial photos were also analyzed, with the help of which the study of those areas could be also integrated with the modern investigations, which are now inaccessible for archaeological research. The most voluminous study in the volume is presented by L. Borhy, K. Dévai, A. Bózsa and E. Számadó (pp. 97-186), filling a gap in the research, concerning the western cemetery of the civil town of Brigetio. The 2009-2010 excavations (Komárom-Lidl supermarket) recovered 87 graves, 42 of which were cremation burials, and 31 were inhumations. The most prominent one in this latter group was a sarcophagus burial, but unfortunately in disturbed condition. In addition to providing a complete inventory of the burials, the authors discuss burial customs, and evaluate the grave finds - dating from the 1st and 2 nd centuries - according to object types. Among them, the ivory writing tablet and a jar covered with a lid were unique (grave 40). The study contains a complete catalogue, including the drawings and photos of the graves, as well as of grave finds (edited in separate tables) (Figs.1-51). A. Bödöcs (pp. 187-194) evaluates the structural patterns of the western segment of this cemetery (excavated in 2009), which could be predominantly dated to the Early Imperial Period. Apart from certain parts of the cemetery fragment, which were in an unsuitable condition for documentation, three grave groups could be established, based on the orientation and position of the graves; their closest parallels can be found in the cemetery at Nemesböd-Cserpregi-völgyre-dülő II (in County Vas). Complementing the aforementioned two studies, M. Merczi (pp. 195214) carries out the anthropological analysis of the cemetery. The 31 inhumations - dating from the Early and Late Imperial Periods - were badly preserved; based on the evaluation of cranial size range, there is no 
significant difference to be observed in comparison to other cemeteries in Northeastern Pannonia. The disturbed sarcophagus preserved the remains of a 12-14 year old girl, of a small adult, and of a large female (maturus) individual. B. Simon's study (pp. 215-222), attempts to define the locate the site (KomáromSzőny-Vásártér-élelmiszer áruház) of the 1970 excavation of E. Bíró. Allowing a certain degree of difference, the documented feature could be connected to the now established plan of the area - using GIS and archive photos; magnetometric surveys and the actual excavation of the area could bring further results. Consisting 152 entries, N. Sey compiled a register of bones finds found in the castra legionis and of the finds from the bronze workshop excavated in 2014 in the area of the canabae, east of the aforementioned "bathhouse"(Szőny-Dunapart) (pp. 223-242). Among the bone finds, a disk carved from an ivory tusk should be noted (Cat. 21.). Z. Kis (pp. 243-258) presents thin walled ceramic finds from Brigetio, decorated with barbotine. There are 27 entries in his catalogue, and - based on the analysis of (mostly floral) ornaments, he identified 14 variations. Cs. Sáró (pp. 259-280) presents a catalogue of grave stones (including 19 entries) found in County Komárom-Esztergom, on which elements of female ("indigenous") costumes could be documented. Notably, the types of brooches were matching the archaeological finds, and formal differences within certain types (Norican-Pannonian wing brooches) could be also established. The "indigenous" character, as a terminological definition emphasized in earlier studies, should be revised, since the respective dress accessories were not simply elements of a local cultural milieu (e.g. hinged brooch types), and their distribution was not limited to the local context. E. Soós and K. Tankó (pp. 281-301) evaluated the results of a 2005 excavation of a settlement, which had a Germanic-like character, was situated in the Barbaricum (in Pásztó-Csontfalva, County Nógrád), and was dated to the Late Roman Period (C3). This site is the only one of its kind in the region, and although its structure fits into the Germanic context, the finds displayed different tendencies (hand built and wheel thrown ceramics, without decorations), the evaluation of which requires more extensive regional research. 